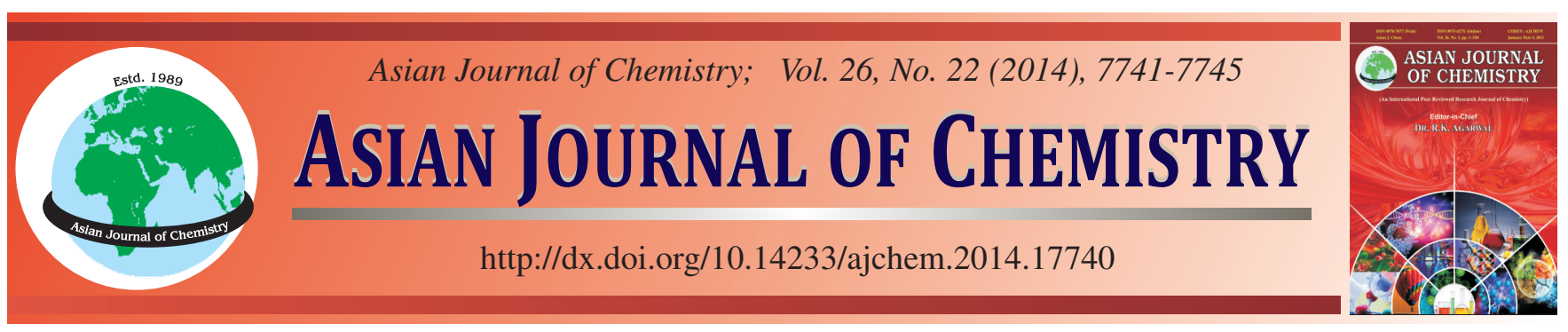

\title{
Chemical Composition and Antimicrobial Activity of Essential Oils of Stems of Macleaya cordata (Willd) R. Br.
}

\author{
Chunmei Li and JianPing Yu*
}

Institute of Biochemistry and Nutrition, Guizhou University, Guiyang 550025, P.R. China

*Corresponding author: Tel: +86 851 3856374; E-mail: Yujp666666@163.com

\begin{abstract}
The essential oil from the stems of Macleaya cordata R.Br. obtained by hydrodistillation was analyzed by gas chromatography/mass spectrometry. Fifty compounds consisting up to $99.17 \%$ of the essential oil were identified by GC and GC/MS analysis. The essential oil exhibited potential antimicrobial activity against all tested microorganisms, with diameters of inhibition zones ranging from $7.7 \pm 0.6$ to $16.9 \pm 0.8 \mathrm{~mm}$ and MIC values from 125 to $500 \mu \mathrm{g} / \mathrm{mL}$. To understand the antibacterial mechanism of the essential oil, we selected the sensitive bacterium $R$. solanacarum as model to observe of the action of essential oils of $M$. cordata on the membrane structure by SEM. The treated cell membranes were damaged severely; resulting in cell atrophy and condenses into clusters, lost the original rod structure. The results presented here indicate that the essential oil of $M$. cordata has antimicrobial properties and is therefore a potential source of antimicrobial agents for many industries in the future.
\end{abstract}

Keywords: Macleaya cordata, Essential oils, Chemical composition, Antimicrobial activity.

\section{INTRODUCTION}

The continuing development of bacterial and fungicidal resistance in human and plant pathogens necessitates the discovery and development of new antimicrobials ${ }^{1-4}$. Plant secondary metabolites originate from the interaction between plants and environment during the long period of evolution in plants and play an important role in protecting plants against invasion. Essential oils and their components have been proved to possess many biological activities including antimicrobial, insecticidal and antioxidant activities ${ }^{5-8}$ and they have attained a special interest and development. Today, essential oils with antioxidant and antimicrobial activities is an ideal resource in the filed of research on food and feed additives ${ }^{9-10}$.

Macleaya cordata (Willd) R. Br., a plant of papaveraceae family, has been used as an important and traditional Chinese medicine for a long time for its wide spectrum of biological activities, e.g. antimicrobial, antifungal, antiinflammatory and antitumor $^{11-13}$. This herb is mainly distributed in throughout the south, southeastern and northwest of China. The phytochemical and pharmacological studies conducted on this medicinal herb have successfully isolated several alkaloids ${ }^{14}$. Several quaternary benzo[c] phenanthridine alkaloids from $M$. cordata which exhibited cytotoxicity ${ }^{15,16}$, protease inhibitory ${ }^{17}$, antimicrobial $^{18}$, molluscicidal ${ }^{19}$ and insecticidal activities ${ }^{20,21}$. antiinflammatory ${ }^{22,23}$, antitumor activity ${ }^{24,25}$, antiviral ${ }^{26-28}$.
M. cordata has attracted much attention from investigators depending on its bioactive alkaloids ${ }^{18}$, however, the other chemical compositions of $M$. cordata were rarely investigated. The literature data for the chemical composition of the essential oil from $M$. cordata are scarce, according to our best of knowledge, there is only one report on the chemical composition of the essential oil of $M$. cordata ${ }^{29}$, in the literature and its antimicrobial potentials have not been evaluated so far. The aim of the present study was to analyze the chemical composition of the stems essential oil of $M$. cordata from China as well as to evaluate its antimicrobial activity and mechanism.

\section{EXPERIMENTAL}

Analytical grade ethanol, dimethyl sulphoxide, anhydrous sodium sulphate, sodium carbonate and all cultures media were obtained from Green Ltd. (Guiyang, China). Ultra pure water was used for the experiments. The shape of $R$. solanacarum was observed with a scanning electron microscopy (SEM) (HitachiS-3400N). Absorbance was measured using a UVvisible spectrophotomwter (TU-1901, China).

Plant material: $M$. cordata were collected in Guizhou Province of China during August 2012 and their roots, stems and leaves were separated, dried in the shade at room temperature and ground ( 80 mesh). The taxonomical identification of the plant material was done by Prof. Haimin Liao of Guizhou University. An authenticated specimen (GZIBN-20120813) of 
the plant was also deposited in the Institute of Biochemistry and Nutrition, Guizhou University.

Isolation of the essential oils: Crushed stems were submitted to hydrodistillation in a Clevenger-type apparatus at $100{ }^{\circ} \mathrm{C}$ for $6 \mathrm{~h}$. The distilled essential oils were dried over anhydrous sodium sulphate, filtered and preserved in a sealed brown glass vial at $4{ }^{\circ} \mathrm{C}$ until tested and analyzed.

Analysis of essential oil: Gas chromatography-mass spectrometry (GC-MS) analysis was performed on a Agilent 6890 N GC/5975MSD-SCAN (Agilent Technologies, Palo Alto, CA,USA) in the electron impact (EI) ionization mode $(70 \mathrm{eV})$ and zebron ZB-5Msi (bonded and cross-linked $5 \%$ phenyl-95\% Dimethyl polysiloxane, $30 \mathrm{~m}$ length and $0.25 \mathrm{~mm}$ I.D., $0.25 \mu \mathrm{m}$ film thickness) capillary column (Phenomenex, Torrance, USA). The inlet and GC/MS interface temperatures were kept at 250 and $280{ }^{\circ} \mathrm{C}$, respectively. The temperature of $\mathrm{El} 70 \mathrm{eV}$ source was $230^{\circ} \mathrm{C}$ with full scan $(20-480 \mathrm{~m} / \mathrm{z})$. The oven temperature was held at $50{ }^{\circ} \mathrm{C}$ for $2 \mathrm{~min}$, then programmed to $310^{\circ} \mathrm{C}$ at rate of $5{ }^{\circ} \mathrm{C} / \mathrm{min}$ kept constant at $310^{\circ} \mathrm{C}$ for $8 \mathrm{~min}$. The split ratio was 1:40. Helium $(99.99 \%)$ was the carrier gas at a flow rate of $1 \mathrm{~mL} / \mathrm{min}$. Diluted samples $(1 / 100$ in hexane, v/v) were injected manually. The mass spectra of essential oil and extract components were identified by comparing the mass spectra of the analytes with those of authentic standards from the mass spectra of Wiley 275 and Mass Spectra Library (Nist 2005). The relative concentration of each compound in essential oil was quantified according to the peak area integrated by the analysis program ${ }^{30,31}$.

\section{Antimicrobial activity}

Microbial strains: The essential oil of $M$. cordata were individually tested against a set of eight microorganisms. Following microbial strains were used in this research: Three Gram-positive (Bacillus subtilis ATCC 6633, Staphylococcus aureus ATCC 27217 and Staphylococcus haemolyticus ATCC 29213). Three Gram-negative (Ralstonia solanacarum GMI 1000, Agrobacterium tume faciens ATCC 11158, Escherichia coli CMCC 44102), and one fungus (Aspergillus niger CMCC 98003), one yeast (Candida albicans ATCC 10231) and microbial were selected for antimicrobial activity assay. Bacterial strains were cultured $24 \mathrm{~h}$ at $37^{\circ} \mathrm{C}$ in liquid LB medium (yeast extract $5 \mathrm{~g} / \mathrm{L}$, peptone $10 \mathrm{~g} / \mathrm{L}, \mathrm{NaCl} 5 \mathrm{~g} / \mathrm{L}, \mathrm{pH} 7$ ), Fungus and yeast were cultured overnight at $28^{\circ} \mathrm{C}$ for $48 \mathrm{~h}$ in liquid potato dextrose (PD) medium. The diluted microbial suspension $\left(10^{6}\right.$ $\mathrm{cfu} / \mathrm{mL}$ ) was ready for assay.

Disc diffusion assay: Determination of antimicrobial activities of the essential oil of $M$. cordata were accomplished by the standard disc diffusion method ${ }^{32}$. The essential oil was dissolved in dimethyl sulfoxide at an initial concentration of 10 $\mathrm{mg} / \mathrm{mL}$ and sterilized after being filtered by $0.45 \mu \mathrm{m}$ Millipore filters, respectively. Bacteria suspensions were spread on these media by sterile swab. Each disc ( $6 \mathrm{~mm}$ in diameter) was injected $10 \mu \mathrm{L}$ of $10 \mathrm{mg} / \mathrm{mL}$ sample, then the discs were placed on the plates one by one. Negative controls were prepared using DMSO. Gentamycin $(20 \mu \mathrm{g} /$ disc $)$ were used as positive controls for bacteria and nystatin $(20 \mu \mathrm{g} / \mathrm{disc})$ for fungi and yeasts. Standard antibiotic discs which were selected for suitable microorganisms, were placed into the same plates as positive controls. An empty disc was used to test if discs were sterile or not. The inoculated plates were incubated at $37^{\circ} \mathrm{C}$ for $24 \mathrm{~h}$ for the bacterial strains, at $27^{\circ} \mathrm{C}$ for 72 and $48 \mathrm{~h}$ for the fungus and yeast. The zone of inhibition against the tested microorganisms were measured and the antimicrobial activity was evaluated.

Determinations of the minimum inhibitory concentration (MIC): The sample were dissolved in DMSO at an initial concentration of $10 \mathrm{mg} / \mathrm{mL}$ and filtered by $0.45 \mu \mathrm{m}$ Millipore filters for sterilization. Serial broth dilution method was carried out as described by Muroi and $\mathrm{Kubo}^{33}$. Solutions of the essential oil ranging from 1000 to $7.8 \mu \mathrm{g} / \mathrm{mL}$ were prepared by serial two fold dilutions. A suspension of each microorganism $\left(\left(10^{6} \mathrm{cfu} / \mathrm{mL}\right)\right.$ was obtained by measuring the absorbance of the solution at wavelength $620 \mathrm{~nm}$ using a ultraviolet spectrometer. the successive dilutions of the oils samples and $1 \mathrm{~mL}$ portions of the culture media were placed in the test tubes; then mixed with $20 \mathrm{~mL}$ of the cell suspensions. The microbial growth was examined after bacteria being incubated at $37^{\circ} \mathrm{C}$ for $24 \mathrm{~h}$. The same procedure was performed for fungi and yeast incubated for $48 \mathrm{~h}$ at $28{ }^{\circ} \mathrm{C}$. Gentamycin for bacteria and nystatin for fungi were used as standard drugs for positive control in the conditions identical to that of the tests materials. The results are expressed in Minimal inhibitory concentration (MIC), the weakest concentration of the samples yielding no visible growth. Microorganism growth was indicated by turbidity. The MICs of the standards (gentamycin, nystatin) were also determined in parallel experiments, to control for the sensitivity of the microorganisms. The bactericidal/fungicidal activities were determined by a sub-cultivation of the samples into normal culture media at appropriate temperature and incubation times.

Observation of the action on $R$. solanacarum cells by scanning electron microscopy: Different volume of LB medium, essential oils solutions and $R$. solanacarum cells were added to $10 \mathrm{~mL}$ cultures resulting in final concentration of $100 \mu \mathrm{g} / \mathrm{mL}$ of the essential oils and concentration of $10^{6} \mathrm{cfu} / \mathrm{mL}$ $R$. solanacarum. Control experiment was conducted in absence of essential oils. The cultures were incubated at $37{ }^{\circ} \mathrm{C}$ with shaking at $150 \mathrm{rpm}$. After $12 \mathrm{~h}$, bacterial suspension was washed three times with PBS buffer and then fixed with $4 \%$ glutaraldehyde solution at $4{ }^{\circ} \mathrm{C}$ for $12 \mathrm{~h}$. After the reaction completed, the fixed bacterias were then washed with 30, 50, 70, 80, 90 and $100 \%$ of ethanol respectively. After gold spraying and freezing-drying in a high vacuum, the shape of bacteria was observed using a scanning electron microscopy.

\section{RESULTS AND DISCUSSION}

Chemical composition of the essential oil: Air-dried stems of the plant were subjected to hydrodistillation using a Clevenger-type apparatus and the yellow-coloured oil was obtained in the yield of $0.089 \%$ (w/w). The total ion map of essential oil from the leaves of of $M$. cordata was showed in Fig. 1 and 50 compounds consisting up to $99.17 \%$ of the essential oil were identified by GC and GC/MS analysis (Table-1). The major components (relative content $\geq 1 \%$ ) are palmitic acid $37.52 \%$, pentadecanal $8.74 \%$, butyl phthalate $7.43 \%$, linoleic acid 5.89\%, (E)-9,17-octadecadienal $3.63 \%$, nonadecane $3.57 \%$, myristic acid $3.51 \%$, octoil $3.42 \%$, 
TABLE-1

PHYTOCHEMICAL COMPOSITIONS OF THE ESSENTIAL OILS FROM THE STEMS OF M.cordata

\begin{tabular}{|c|c|c|c|c|}
\hline No. & Compounds & Molecular formula & $\mathrm{RT}^{\mathrm{a}}$ & Composition (\%) \\
\hline 1 & Benzaldehyde & $\mathrm{C}_{7} \mathrm{H}_{6} \mathrm{O}$ & 6.89 & 0.05 \\
\hline 2 & Hyacinthin & $\mathrm{C}_{8} \mathrm{H}_{8} \mathrm{O}$ & 9.08 & 0.24 \\
\hline 3 & Nonanal & $\mathrm{C}_{9} \mathrm{H}_{18} \mathrm{O}$ & 10.68 & 0.08 \\
\hline 4 & (E)-2-Nonenal & $\mathrm{C}_{9} \mathrm{H}_{16} \mathrm{O}$ & 12.27 & 0.05 \\
\hline 5 & Caprylic acid & $\mathrm{C}_{8} \mathrm{H}_{16} \mathrm{O}_{2}$ & 13.28 & 0.13 \\
\hline 6 & Decanal & $\mathrm{C}_{10} \mathrm{H}_{22} \mathrm{O}$ & 13.53 & 0.26 \\
\hline 7 & 2-Undecanone & $\mathrm{C}_{11} \mathrm{H}_{22} \mathrm{O}$ & 15.94 & 0.1 \\
\hline 9 & 4-Vinyl-2-methoxy-phenol & $\mathrm{C}_{9} \mathrm{H}_{10} \mathrm{O}_{2}$ & 16.75 & 0.17 \\
\hline 10 & Capric acid & $\mathrm{C}_{10} \mathrm{H}_{20} \mathrm{O}_{2}$ & 18.42 & 0.4 \\
\hline 11 & Tetradecane & $\mathrm{C}_{14} \mathrm{H}_{30}$ & 18.69 & 0.14 \\
\hline 12 & Geranyl acetone & $\mathrm{C}_{13} \mathrm{H}_{22} \mathrm{O}$ & 20.09 & 0.16 \\
\hline 13 & 2,6-di-butyl-2,5-cyclohexadiene-1,4-dione & $\mathrm{C}_{14} \mathrm{H}_{20} \mathrm{O}_{2}$ & 20.54 & 0.37 \\
\hline 14 & 2,6-di(t-butyl)-4-hydroxy-4-methyl-2,5-cyclohexadien-1-one & $\mathrm{C}_{15} \mathrm{H}_{24} \mathrm{O}_{2}$ & 20.7 & 0.19 \\
\hline 15 & $\beta$-Ionone & $\mathrm{C}_{13} \mathrm{H}_{20} \mathrm{O}$ & 20.99 & 0.35 \\
\hline 17 & Lauric acid & $\mathrm{C}_{12} \mathrm{H}_{24} \mathrm{O}_{2}$ & 23.39 & 1.87 \\
\hline 18 & Hexadecane & $\mathrm{C}_{16} \mathrm{H}_{34}$ & 23.56 & 0.51 \\
\hline 19 & 2-Cedrol & $\mathrm{C} 15 \mathrm{H} 26 \mathrm{O}$ & 23.96 & 1.37 \\
\hline 20 & Butyl phosphate & $\mathrm{C}_{12} \mathrm{H}_{27} \mathrm{O}_{4} \mathrm{P}$ & 24.87 & 0.48 \\
\hline 21 & 1-Heptadecene & $\mathrm{C}_{17} \mathrm{H}_{34}$ & 25.38 & 0.29 \\
\hline 22 & 2-Pentadecanone & $\mathrm{C}_{15} \mathrm{H}_{30} \mathrm{O}$ & 25.86 & 0.34 \\
\hline 23 & Pentadecanal & $\mathrm{C}_{15} \mathrm{H}_{30} \mathrm{O}$ & 26.21 & 8.74 \\
\hline 24 & Hexadecanal & $\mathrm{C}_{16} \mathrm{H}_{32} \mathrm{O}$ & 26.44 & 0.5 \\
\hline 25 & Myristic acid & $\mathrm{C}_{14} \mathrm{H}_{28} \mathrm{O}_{2}$ & 27.78 & 3.51 \\
\hline 26 & $6,10,14$-Trimethyl-pentadecanone & $\mathrm{C}_{18} \mathrm{H}_{36} \mathrm{O}$ & 28.95 & 0.9 \\
\hline 27 & Isobutyl phthalate & $\mathrm{C}_{16} \mathrm{H}_{22} \mathrm{O}_{4}$ & 29.5 & 2.13 \\
\hline 28 & Pentadecylic acid & $\mathrm{C}_{15} \mathrm{H}_{20} \mathrm{O}_{2}$ & 29.68 & 1.94 \\
\hline 29 & (E)-9,17-Octadecadienal & $\mathrm{C}_{18} \mathrm{H}_{32} \mathrm{O}$ & 29.86 & 3.63 \\
\hline 30 & Nonadecane & $\mathrm{C}_{19} \mathrm{H}_{40}$ & 30.02 & 3.57 \\
\hline 31 & Farnesyl acetone & $\mathrm{C}_{18} \mathrm{H}_{30} \mathrm{O}$ & 30.46 & 0.25 \\
\hline 33 & Butyl phthalate & $\mathrm{C}_{16} \mathrm{H}_{22} \mathrm{O}_{4}$ & 31.39 & 7.43 \\
\hline 34 & Palmitic acid & $\mathrm{C}_{16} \mathrm{H}_{32} \mathrm{O}_{2}$ & 31.91 & 37.52 \\
\hline 35 & Methyl linoleate & $\mathrm{C}_{19} \mathrm{H}_{34} \mathrm{O}_{2}$ & 33.82 & 0.71 \\
\hline 36 & Linoleic acid & $\mathrm{C}_{18} \mathrm{H}_{32} \mathrm{O}_{2}$ & 34.91 & 5.89 \\
\hline 37 & Tricosane & $\mathrm{C}_{23} \mathrm{H}_{48}$ & 37.35 & 0.49 \\
\hline 38 & Tetracosane & $\mathrm{C}_{24} \mathrm{H}_{50}$ & 39 & 0.52 \\
\hline 39 & Pentacosane & $\mathrm{C}_{25} \mathrm{H}_{52}$ & 40.59 & 1.28 \\
\hline 40 & Octoil & $\mathrm{C}_{24} \mathrm{H}_{38} \mathrm{O}_{4}$ & 41.41 & 3.42 \\
\hline 41 & Hexacosane & $\mathrm{C}_{26} \mathrm{H}_{54}$ & 42.12 & 0.83 \\
\hline 42 & Heptacosane & $\mathrm{C}_{27} \mathrm{H}_{56}$ & 43.6 & 1.02 \\
\hline 43 & Squalane & $\mathrm{C}_{30} \mathrm{H}_{62}$ & 44.13 & 0.95 \\
\hline 44 & Octacosane & $\mathrm{C}_{28} \mathrm{H}_{58}$ & 45.02 & 1.18 \\
\hline 45 & Nonacosane & $\mathrm{C}_{29} \mathrm{H}_{60}$ & 46.4 & 0.8 \\
\hline 46 & Triacontane & $\mathrm{C}_{30} \mathrm{H}_{62}$ & 47.72 & 0.77 \\
\hline 47 & Hentriacontane & $\mathrm{C}_{31} \mathrm{H}_{64}$ & 49.03 & 0.91 \\
\hline 48 & (17.a.H,21.B.H)-Hopane & $\mathrm{C}_{30} \mathrm{H}_{52}$ & 49.88 & 0.82 \\
\hline 49 & Dotriacontane & $\mathrm{C}_{32} \mathrm{H}_{66}$ & 50.26 & 0.49 \\
\hline \multirow[t]{2}{*}{50} & Tritriacontane & $\mathrm{C}_{33} \mathrm{H}_{68}$ & 51.48 & 0.58 \\
\hline & Total & - & - & 99.17 \\
\hline
\end{tabular}

isobutyl phthalate $2.13 \%$, pentadecylic acid $1.94 \%$, lauric acid $1.87 \%$, 2-cedrol $1.37 \%$, pentacosane $1.28 \%$, octacosane $1.18 \%$ and heptacosane $1.02 \%$. comprising $84.50 \%$ of the essential oils. Saturated fatty acids, alkanes, unsaturated fatty acids, aromatic compounds, terpenoids, Other aliphatic compounds in the oil accounted for 46.10, 14.34, 6.60, 16.06, 1.18 and $14.89 \%$, respectively. The chemical profile of the stem bark essential oil of $M$. cordata in this study was different from that of the previous reports ${ }^{29}$. Distinct differences in the yield and composition of essential oils from $M$. cordata may be arise from environment, tested parts, growth season, physiological age of the plant and the method of isolation.

Antimicrobial activity: The antimicrobial activities of the essential oil were estimated against eight tested microorganisms, including three Gram-negative bacteria, three Gram-positive bacteria, one fungus and one yeast. The diameters of the zones of inhibition and the MICs of the essential oil are shown in Table-2. The diameters of inhibition zones 


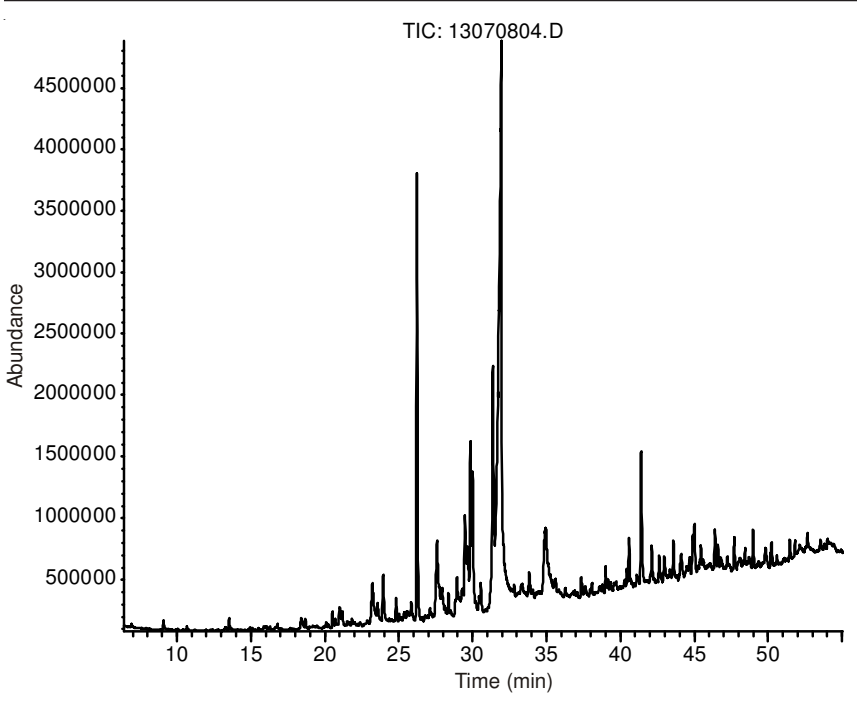

Fig. 1. Total ion map of essential oil from the stems of of $M$. cordata

of the oil on test microorganisms ranged from $7.7 \pm 0.6$ to $15.9 \pm 0.8 \mathrm{~mm}$ and the MIC values ranged from 125 to $500 \mu \mathrm{g} / \mathrm{mL}$. Among all tested microorganisms $R$. solanacarum and $S$. aureus were more sensitive to the essential oil, with the MIC values of $125 \mu \mathrm{g} / \mathrm{mL}$. The diameters of inhibition zones of the essential oil against $R$. solanacarum and $S$. aureus were 15.9 \pm 0.8 and $15.1 \pm 1.0 \mathrm{~mm}$, respectively. The oil also showed antifungal activities against one fungus and one yeast. The antimicrobial activities of the essential oil against bacteria and fungi were demonstrated to be dose dependent. The inhibition zones of the essential oil for each assay on test bacteria showed a significant correlation with MIC values $(\mathrm{P}<0.05)$. Control treatment (DMSO) did not show an inhibitor effect on any of the bacteria.

Action of the essential oil of $M$. cordata on the structures of $\boldsymbol{R}$. solanacarum cells: Though this research found the essential oil of $M$. cordata could inhibit bacterial growth, the mode of action of essential oil on the bacteria is still unknown. In this paper, to understand the antibacterial activity and acting mechanism of the essential oil of $M$. cordata, the sensitive bacteria $R$. solanacarum was selected as the tested microorganism. The action of the essential oil of $M$. cordata on the structures of $R$. solanacarum cells was studied.
The electron micrographs by scanning electron microscopy of $R$. solanacarum cells treated and untreated with the essential oil of $M$. cordata were displayed in Fig. 2. Micrograph by SEM (Fig. 2a) showed the surface of $R$. solanacarum cells untreated with the essential oil of $M$. cordata was smooth and showed typical characters of rod shape, while cells treated with $100 \mu \mathrm{g} / \mathrm{mL}$ essential oil (Fig. 2b) were damaged severely, resulting in cell atrophy and condenses into clusters, lost the original rod structure. A large number of misshapen and fragmentary bacterial cells can be seen from micrographs. We hypothesized that the acting mechanism of the essential oil from $M$. cordata antibacterial activity are the structure and permeability of cell membrane of treated bacteria changed, so that the substances exuded in the cytoplasm, at last cells dehydrate, atrophy and crack. This hypothesis needs to be further proved.
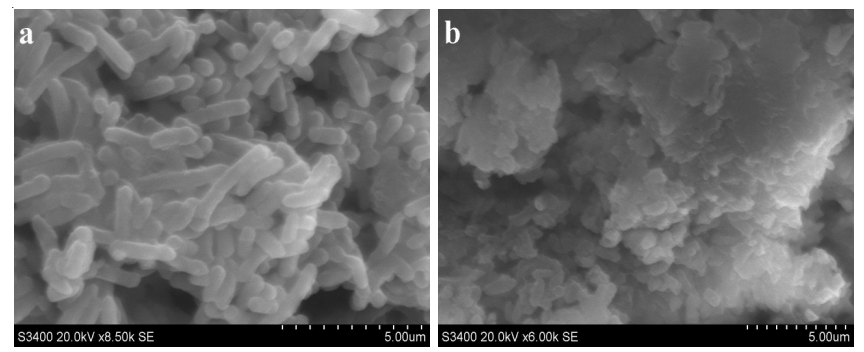

Fig. 2. Action of the essential oil of $M$. cordata on the structures of $R$. solanacarum cells observed by SEM. (a) native $R$. solanacarum. (b) treated with $100 \mu \mathrm{g} / \mathrm{mL}$ the essential oil

\section{Conclusion}

This is the first report on the antimicrobial activities of $M$. cordata essential oil. The essential oil was screened to show a wide spectrum of inhibitory activity against pathogenic bacteria, fungi and yeast. The antimicrobial activity of the stems essential oil of $M$. cordata could be attributed by major compounds. It has also been suggested that minor components interact with the other components, affecting the antimicrobial activities of the oils. It is possible that the activity of the main components is regulated by the other minor molecules.

\begin{tabular}{|c|c|c|c|c|c|c|}
\hline \multirow{3}{*}{ Microorganisms } & \multicolumn{4}{|c|}{$\begin{array}{l}\text { TABLE-2 } \\
\text { ANTIMICROBIAL ACTIVITY OF THE ESSENTIAL OIL OF } M \text {. cordata }\end{array}$} & & \\
\hline & \multicolumn{2}{|c|}{ Essential oil } & \multicolumn{2}{|c|}{ Gentamicin } & \multicolumn{2}{|c|}{ Nystatin } \\
\hline & Disc diameter $^{\mathrm{b}}$ & $\mathrm{MIC}^{\mathrm{c}}$ & Disc diameter & MIC & Disc diameter & MIC \\
\hline \multicolumn{7}{|l|}{ Gram-positive } \\
\hline B. subtilis ATCC 6633 & $9.2 \pm 0.7$ & 250 & $26.1 \pm 1.1$ & 7.8 & - & - \\
\hline S. aureus ATCC 27217 & $15.1 \pm 1.0$ & 125 & $26.9 \pm 0.7$ & 7.8 & - & - \\
\hline S. haemolyticus ATCC 29213 & $14.1 \pm 1.1$ & 250 & $25.4 \pm 1.1$ & 7.8 & - & - \\
\hline \multicolumn{7}{|l|}{ Gram-negative } \\
\hline A. tumefaciens ATCC 11158 & $11.5 \pm 1.4$ & 500 & $30.1 \pm 1.6$ & 15.6 & - & - \\
\hline R. solanacarum GMI1000 & $15.9 \pm 0.8$ & 125 & $24.7 \pm 1.2$ & 7.8 & - & - \\
\hline E. coli CMCC44102 & $7.7 \pm 0.6$ & 500 & $23.8 \pm 0.9$ & 7.8 & - & - \\
\hline \multicolumn{7}{|l|}{ Fungi } \\
\hline A. niger $\mathrm{CMCC}(\mathrm{B}) 98003$ & $12.9 \pm 0.8$ & 250 & - & - & $23.4 \pm 1.0$ & 31.3 \\
\hline \multicolumn{7}{|l|}{ Yeast } \\
\hline C. albicans ATCC 10231 & $11.1 \pm 1.2$ & 250 & - & - & $22.4 \pm 1.5$ & 15.6 \\
\hline
\end{tabular}

${ }^{a}$ Results are means of three different experiments, ${ }^{b}$ Diameter of inhibition zone including disc diameter of 6 (mm), Mean \pm standard deviation for triplicate experiments, ${ }^{c} \mathrm{MIC}$, minimum inhibitory concentration (as $\left.\mu \mathrm{g} / \mathrm{mL}\right)$ 
To understand the antibacterial mechanism of the essential oil to bacteria, we first selected $R$. solanacarum as model to observe of the action of essential oils of $M$. cordata on the membrane structure of $R$. solanacarum. The SEM micrograph of $R$. solanacarum cells treated with the essential oils showed that big change appeared in the cell membrane and cell atrophy and condenses into clusters, lost the original rod shape. $R$. solanacarum cells treated with the essential oil also showed many fragmentary cells by SEM. According to the results of this study, the essential oil of $M$. cordata may be suggested as a new potential source of natural antimicrobial. This is the first report on the antimicrobial activity of essential oil from $M$. cordata, though further work is now required to evaluate the antimicrobial compounds and mechanism, In addition, other biological activities of the essential oil of $M$. cordata is now required to further develop.

\section{ACKNOWLEDGEMENTS}

This work was financially supported by the Natural Science Foundation of Guizhou Province (NY[2011]3094, [2010] 4008, [2010]3072 and [2009]7012-1).

\section{REFERENCES}

1. D.L. Zink, Emerg. Infect. Dis., 3, 467 (1997).

2. S. Brul and P. Coote, Int. J. Food Microbiol., 50, 1 (1999).

3. K.M. Schuenzel and M.A. Harrison, J. Food Prot., 65, 1909 (2002).

4. V.A. Shanmuganathan, M. Armstrong, A. Buller and A.B. Tullo, Eye, 19, 284 (2005)

5. N. Dudareva, F. Negre, D.A. Nagegowda and I. Orlova, Crit. Rev. Plant Sci., 25, 417 (2006).

6. C. Sarikurkcu, K. Arisoy, B. Tepe, A. Cakir, G. Abali and E. Mete, Food Chem. Toxicol., 47, 2479 (2009).

7. M. Zuzarte, M.J. Gonçalves, C. Cavaleiro, J. Canhoto, L. Vale-Silva, M.J. Silva, E. Pinto and L. Salgueiro, J. Med. Microbiol., 60, 612 (2011).

8. H.J. Yeom, J.S. Kang, J.H. Kim and I.K. Park, J. Agric. Food Chem., 60, 7194 (2012)

9. S. Burt, Int. J. Food Microbiol., 94, 223 (2004).

10. S. Singh, I.P.S. Kapoor, G. Singh, C. Schuff, M.P. Lampasona and C.A.N. Catalan, Proc. Natl. Acad. Sci., India, Sect. B Biol. Sci., 83, 357 (2013).
11. F. Feng, F.Z. Ye, C.L. Li, W.Y. Liu and N. Xie, Chinese J. Nat. Med., 10, 0378 (2012).

12. L. Ouyang, X.L. Su, D.S. He, Y.Y. Chen, M. Ma, Q.J. Xie and S.Z. Yao, J. Sep. Sci., 33, 2026 (2010)

13. J. Tian, J.P. Yu, Y.H. Ge, L.Y. Qi and C.M. Li, Pa. Med., 32, 1108 (2010).

14. Z.B. Hu, Y. Xu, S.C. Feng and G.J. Fan, Acta Pharmacol. Sin., 14, 535 (1979).

15. F.R. Stermitz, K.A. Larson and D.K. Kim, J. Med. Chem., 16, 939 (1973).

16. J. Vrba, P. Dolezel, J. Vicar and J. Ulrichova, Toxicol. in Vitro, 23, 580 (2009).

17. O.V. Iagodina, E.B. Nikol'skaia and M.D. Faddeeva, Tsitologiia, 45, 1032 (2003).

18. P. Kosina, J. Gregorova, J. Gruz, J. Vacek, M. Kolar, M. Vogel, W. Roos, K. Naumann, V. Simanek and J. Ulrichova, Fitoterapia, 81, 1006 (2010).

19. M. Zhong, G.Y. LI, J.G. Zeng, L. Zhang, K.L. Huang, J.M. She, X. Li and W.Y.Wei, J. Med. Plants Res., 5, 521 (2011).

20. K. Wang, C. Luo and H. Liu, Afr. J. Agric. Res., 7, 5925 (2012).

21. J.Y. Yao, J.Y. Shen, X.L. Li, Y. Xu, G.J. Hao, X.Y. Pan, G.X. Wang and W.L. Yin, Parasitol. Res., 107, 1035 (2010).

22. J. Lenfeld, M. Kroutil, E. Marsalek, J. Slavik, V. Preininger and V. Simanek, Planta Med., 43, 161 (1981).

23. K. Pencíková, P. Kollár, V. Müller Závalová, E. Táborská, J. Urbanová and J. Hošek, Phytomedicine, 19, 890 (2012).

24. B.C. Jang, J.G. Park, D.K. Song, W.K. Baek, S.K. Yoo, K.H. Jung, G.Y. Park, T.Y. Lee and S.I. Suh, Toxicol. in vitro, 23, 281 (2009).

25. H. Park, E. Bergeron, H. Senta, K. Guillemette, S. Beauvais, R. Blouin, J. Sirois and N. Faucheux, Biochem. Biophys. Res. Commun., 399, 446 (2010).

26. Z.F. Zhang, Y. Guo, L.W. Zhang, J.B. Zhang and X.H. Wei, Acta Pharm. Sinica B, 2, 464 (2012).

27. M.L. Colombo and E. Bosisio, Pharmacol. Res., 33, 127 (1996).

28. M.A. Kerry, O. Duval, R.D. Waigh and S.P. Mackay, J. Pharm. Pharmacol., 50, 1307 (1998).

29. L.J. Chen, S.Y. Zhou, H.Z. Shi and J. Yin, Chinese Agric. Sci. Bull., 25, 94 (2009).

30. F. Oke, B. Aslim, S. Ozturk and S. Altundag, Food Chem., 112, 874 (2009).

31. R.P. Adams, Identification of Essential Oil Components by Gas Chromatography/Quadrupole Mass Spectroscopy, Allured: Carol Stream IL, USA., (2001).

32. E.O. Kose, I.G. Deniz, C. Sarikurkcu, O. Aktas and M. Yavuz, Food Chem. Toxicol., 48, 2960 (2010).

33. H. Muroi and I. Kubo, J. Appl. Microbiol., 80, 387 (1996). 